\title{
Assessment of the use of the hydrolyzed liquid fraction of the kiwicha grain in the fermentation process of probiotic drinks from tarwi juice: microbiological, chemical and sensorial analysis
}

\author{
Edilberto Flores AGUILAR ${ }^{1 *}$, Emille del Pilar Flores RIVERA ${ }^{2}$
}

\begin{abstract}
Non-diary probiotic drinks are of interest to the consumers who suffer from lactose intolerance and allergenicity when consuming milk and its derivatives. Its production requires substrates that favor the viability of probiotics in the process and storage. This research assessed the use of the liquid fraction obtained from the enzymatic hydrolysis of kiwicha grain including the microbiological, chemical and sensory characteristics of probiotic drinks of tarwi juice during fermentation and storage using: Lactobacillus paracasei, B. bacterium longum and a culture of both microorganisms. The viability of probiotics in drinks improved with the increase of hydrolyzed kiwicha in the composition of the drink during fermentation and post fermentation, and showed good tolerance to $\mathrm{pH}$. The viability of the Bifid bacterium longum was reduced with the decrease in the $\mathrm{pH}$, but improved in the co-culture with lactobacillus paracasei. The sensory characteristics of the obtained drinks were favorable.
\end{abstract}

Keywords: Lactobacillus paracasei; Bifid bacterium longum; hydrolyzed kiwicha; tarwi; probiotic drinks.

Practical Application: Employment of the liquid fraction obtained from the enzymatic hydrolysis of kiwicha grain in the production of probiotic drinks.

\section{Introduction}

Probiotics are defined as living microorganisms that when administered in appropriate quantities confer health benefits to the consumer (Tamang et al., 2016a, b; Prado et al., 2008; Manzano et al., 2012). In order to be beneficial, they must be present in a large number of $10^{8}$ to $10^{9}$ cells per product gram at the time of consumption (Prado et al., 2008).

Probiotics must meet with certain requirements: viability and number in the industrial processing, ability to survive under harsh conditions in the gastrointestinal tract, resistance to $\mathrm{pH}$ and bile, ability to adhere to epithelial cells in the intestinal walls, colonization in the human intestine, production of antimicrobial substances called bacteriocins, resistance to physical-chemical conditions during processing (Vera-Pingitore et al., 2016; Kandylis et al., 2016). Probiotic microorganisms mainly come from bacteria, principally in the Lactobacillus and bifid bacterium types, but not exclusively. There are probiotics in other groups such as yeasts and filamentous fungi (Prado et al., 2008; Tamang et al., 2016b).

Fermented foods and drinks of dairy and non-dairy origin play an important role in diets worldwide. The consumption of fermented dairy products has been associated with some health risks such as lactose intolerance, high fat content and cholesterol, and presence of allergenic proteins in milk, and the growing tendency to vegetarianism limit the consumption of fermented dairy products (Kandylis et al., 2016). Non-dairy probiotic drinks are not new; several traditional products are

produced in many regions of the world. In addition to these traditional products, new products have been developed based on fruits and vegetables, soy and cereals (Tamang et al., 2016b; Kandylis et al., 2016; Mokoena et al., 2016; Escalante et al., 2016).

Several probiotic bacteria has been used in the production of fermented drinks from fruits, vegetables, and cereals such as: L. rhamnosus, L. casei, B. lactis, L. paracasei, L. plantarum, L. reuteri, L. delbrueckii, L. acidophilus, L. bulgaricus, B. bifidum, L. brevis, S. thermophiles, B. adolescentis, B. infantis, B. breve and B. longum (Shori, 2016; Obando et al., 2010; Londoño et al., 2008). Their viability in fermented drinks depends on their nature, the substrate, the processing conditions and storage (Mondragon, 2004; Reis et al., 2012; Shah et al., 1995; Benavides \& Quicazan, 2009; Mayorga et al., 2009; Silva et al., 2014).

Tarwi (Lupinus mutabili Sweet) is a leguminous found in several regions in Peru; it isn't widely used. However, after debittering or dehydration processes, it is used in several culinary dishes or to obtain lupine flour. Tarwi is rich in proteins (more than $40 \%$ ), fat (approximately 20\%), minerals and other nutrients (Repo, 2014; Carvajal-Larenas et al., 2016). Milk is also produced from tarwi (tarwi juice) to be consumed at breakfast (Jacobsen \& Mujica, 2006).

Probiotic drinks have been produced with tarwi milk with a moderate level of satisfaction, using yogurt cultures that were applied in mixtures of $70-80 \%$ of powdered milk and $20-30 \%$ of

${ }^{1}$ Departamento de Ciencias e Ingenierías Biológicas y Químicas, Escuela Profesional de Ingeniería de Industria Alimentaria, Universidad Católica de Santa María, Arequipa - Perú ${ }^{2}$ Grupo de Investigación y Desarrollo de Alimentos Funcionales, Universidad Católica de Santa María, Arequipa, Perú

*Corresponding author: edicato@yahoo.es 
tarwi milk (Castañeda et al., 2008); Likewise, tarwi yogurt was obtained after inoculation of Streptococcus thermophiles and Lactobacillus delbrueckii ssp bulgaricus to tarwi juice obtained from lupines campestri with $3 \%$ of sucrose and $1.5 \%$ lactose (Jiménez-Martínez et al., 2003).

Kiwicha (Amaranthus caudatus Linnaesu) is an Andean grain rich in protein that has a chemical composition of protein (15.5\%), fat (7.6\%), minerals (3.4\%), fiber (4.7\%), carbohydrates $(68.8 \%)$ and other components that give its nutritional value (Repo, 2014). There has been descriptions of several biological activities of isolated components of amaranth and quinoa as antibacterial, antitumor, antioxidant, anti-inflammatory and antihypertensive (Carrillo et al., 2015).

Several authors claim that hydrolysis of kiwicha with amylolitic enzymes produces amaranth flour with higher content of protein and carbohydrates that can be a useful ingredient for hypercaloric drinks for athletes (Maza, 2000). In addition, consumption of oligosaccharides favors the proliferation of bifid bacteria in the colon, which are beneficial and combat pathogen bacteria. Similarly, raffinose and stachyose, present in the amaranth seeds, when not hydrolyzed by $a$-amilasa, are contained in the fraction rich in carbohydrates, which may play an important role in the protective effects for health mentioned above.

The application of probiotic cultures in several dairy and non-dairy food matrixes in the production of drinks may affect the viability of probiotics, its capacity to adapt in several substrates, the processing conditions, $\mathrm{pH}$ variations, acidity and its behavior in post-fermentation and the sensorial characteristics in the products.

The purpose of this research was to assess the use of the liquid portion of the hydrolyzed kiwicha on the physical chemical characteristics and the viability of the lactobacillus paracase $i$ BGP1, Bifido bacterium longum SP54 and the mixture of both during fermentation process and in the cold storage of probiotic drinks of tarwi juice. It is expected that the presence of the liquid fraction of hydrolyzed kiwicha determines the viability of such bacteria and improves the quality of the drinks.

\section{Materials and methods}

\subsection{Raw materials, origin and treatments}

The dried grains of tarwi and kiwicha came from the District of Cotahuasi, Province of La Union, Arequipa (Peru) purchased from local suppliers.

Briefly, the grain was soaked for $2 \mathrm{~h}$ ( 1 part of tarwi -5 parts of water), the soaking water was disposed of, and it was cooked for $40 \mathrm{~min}$, twice. This process continued for eight days, carrying out two water changes a day; the grain was pealed, followed by blanching for $1.5 \mathrm{~min}$ at boiling point; rinsed and blanched a second time, adding sodium carbonate in a proportion of $1 \mathrm{~g}$ per $100 \mathrm{~g}$ of tarwi; it was rinsed again, drained and then crushed in a blender. The batter obtained was boiled for 5 minutes, then filtered and pressed, and the solid materials were removed. The juice obtained was boiled for 5-7 min to avoid degradation and also as a measure to increase its shelf life. After boiled, tarwi juice was bottled while hot, cooled quickly and frozen for later use. The amount of juice obtained was regulated to obtain $500 \mathrm{~mL}$ of juice for every $100 \mathrm{~g}$ of tarwi. Tarwi juice contained dry extract, protein, fat, ashes and carbohydrates $(1.3,1.29,0.09,0.052$ and $0 \%$, respectively) and a caloric value of $5.97 \mathrm{kcal} / 100 \mathrm{~g}$.

The hydrolysis of kiwicha was carried out using the grain, previously gelatinized at $92{ }^{\circ} \mathrm{C}$ for $15 \mathrm{~min}$ with a $\mathrm{pH}$ of 5.0 ; the liquefaction was carried out with alpha enzyme - liquid Amilasa Aspergillus Orizae No A8220 (Sigma-Aldrich), pH 5.0, $20 \% \mathrm{p} / \mathrm{p}$ of crushed gelatinized kiwicha grain, $0.2 \%$ of enzyme, $100 \mathrm{ppm}$ of $\mathrm{CaCl}_{2}$, both in weight over the contents of kiwicha in the substrate, $6 \mathrm{~h}$ of incubation at a temperature of $50{ }^{\circ} \mathrm{C}$. The saccharification was carried out using enzyme Gammadex $\mathrm{Cal}-\mathrm{AB}(\mathrm{GmbH}), \mathrm{pH} 4.5,6 \mathrm{~h}$ of incubation at a temperature of $60{ }^{\circ} \mathrm{C}, 0.2 \%$ of enzyme weight over the weight of kiwicha in the substrate $(20 \%$ p/p). Finally, using a sieve, the liquid portion of the hydrolyzed, rich in carbohydrates (HLK) was separated from the solid part or cake, rich in protein; previously, the enzyme was deactivated in the liquid fraction by boiling and the evaporated water levels restored, then it is bottled hot, cooled quickly and frozen for later use. The wet cake was dehydrated in a dryer with hot air. Kiwicha's liquid hydrolyze fraction contained dry extract, protein, fat, ashes and carbohydrates (14, 0.1, 0.25 and $13.3 \%$, respectively) and a caloric value of $55.4 \mathrm{kcal} / 100 \mathrm{~g}$

\subsection{Probiotic dairy bacteria and determination of $\mathrm{CFU}$ number}

Strains of Lactobacillus paracasei (lyofast BGP1) and Bifido bacterium longum (lyofast SP54) were used, imported from Clerici Sacco (Italy.)

Lyophilized strains $(0.01 \mathrm{~g})$ were added to $10 \mathrm{~mL}$ of peptone water (Mondragon, 2004) or tarwi juice, incubation was carried out in a water bath at $37^{\circ} \mathrm{C}$ for $30 \mathrm{~min}$ (Memmert WNB22 with stirrer SV1422). From the incubated medium, dilutions were carried out with peptone water; once the adequate dilution was achieved, plating was carried out in deep using MRS agar with $0.01 \%$ of aniline blue in duplicate according to the procedure previously reported (Mondragon, 2004), then an aliquot of $1 \mathrm{ml}$ of dilution was added in a Petri dish, followed by some $15 \mathrm{ml}$ of agar MRS; the contents were mixed by rotation of the Petri dish and let to cool.

The prepared Petri dishes were placed over an aerobic incubating stove (Selecta, code 2000237) and a culture chamber with a $\mathrm{CO} 2$ atmosphere with a level of $5-10 \%$ at $37{ }^{\circ} \mathrm{C}$ for $72 \mathrm{~h}$ (MMM Med center, Model 500). After the incubation, a count was made of the number of colonies in order to determine the $\mathrm{CFU} / \mathrm{ml}$ of the strain in the incubated medium or the number of CFU/g of the lyophilisate strain. The culture was prepared in the tarwi juice in the same proportion. The counting of the CFU number in the fermentation processes was carried out in a similar way.

\subsection{Assessed formulations and fermentation processes}

Prepared cultures of Lactobacillus paracasei BGP1 (L), Bifido bacterium longum SP54 (B) and one co-culture of both (LB) were inoculated to nine sterilized formulations; the initial number 
of bacteria was of $5.5 \times 10^{6}(\mathrm{Ln} C F U / \mathrm{mL}$ : 15.52$)$ for $\mathrm{L}$ and $\mathrm{B}$, and in the co-culture L: $1 \times 10^{6}$, B: $5.5 \times 10^{6}(\mathrm{Ln} \mathrm{CFU/mL:} \mathrm{15.69),}$ the composition of the assessed formulations are detailed in Table 1. Type 1 formulations do not contain a liquid portion of the hydrolyzed kiwicha (HLK), only tarwi juice (JT), the type 2 formulation contains a proportion of 12.5 and that of type 3 of 25 of HLK with regards to the total. Each formulation was prepared by mixing tarwi juice and kiwicha's liquid hydrolyzate with water and sugar in the proportions indicated in Table 1, followed by sterilization at $115^{\circ} \mathrm{C}$ for $15 \mathrm{~min}$.

The fermentations were carried out in jars containing 50-200 $\mathrm{g}$ of the sample.

In the fermentation and post-fermentation process, $\mathrm{pH}$, acidity, brix degree was assessed with a Jenway $\mathrm{pH}$ meter and 1310 ABBE AR 12 Refractometer Shmidt \& Haensch, respectively. Viability of probiotics was measured according to what was described in the previous item. Fermentation was carried out at $37^{\circ} \mathrm{C}$ in a water bath and it considered complete when the $\mathrm{pH}$ value reached 5.0. The post fermentation process was carried out in refrigeration at $5-6^{\circ} \mathrm{C}$; samples were randomly taken for their assessment at 0,10,20 and 30 days. Humidity, dry extract, protein, fat, ashes, carbohydrates, calcium, sodium, and caloric value was measured in the probiotic drinks

\subsection{Sensorial assessment}

a) The satisfaction level was determined (degree of liking and not liking), a verbal 7 point hedonic scale (Anzaldua, 1994) was applied: 7 (I like it a lot) to 1 (I dislike it a lot); number of semi-trained judges (Espinoza, 2003): 8. It was considered as a favorable rating a satisfaction score for the product of 4.5 .

Table 1. Assessed formulations.

\begin{tabular}{cccccc}
\hline Formulation & JT & HLK & Water & Sucrose & Total \\
\hline 1L, 1B, 1LB & 100 & 0 & 0 & 10 & 110 \\
2L, 2B, 2LB & 87.5 & 12.5 & 1.25 & 8.75 & 110 \\
3L, 3B, 3LB & 75 & 25 & 2.5 & 7.5 & 110 \\
\hline
\end{tabular}

b) The taste was assessed for each type of drink on a scale from 1 to 6 points to determine the useful life of the product, 6 (excellent) to 1 (undrinkable); a rating of 3.5 was considered as a limit, under which it was considered that the product has lost its quality characteristics (Espinoza, 2003). The sensorial assessment was carried out by six trained judges. In addition, the sensory assessment was carried out for drinks with added flavors.

\subsection{Statistical data analysis}

All measurements were obtained in triplicate, and the values were averaged. Data was analyzed with one-way ANOVA post hoc tests, and pairwise multiple comparisons were conducted with either Tukey's or Dunnet's test. Microorganism's viability in fermentation and post fermentation process was carried out, one-way ANOVA followed by Tukey's test $(\mathrm{p}<0.05)$ was analyzed in group of beverages containing the same type of probiotics. Additionally Dunnet's test was applied to compare means referring to the initial number of microorganisms in each formulation in the post-fermentation. Finally, to evaluate significance difference on the sensory assessment one-way ANOVA followed by Tukey's test $(\mathrm{p}<0.05)$ was performed.

\section{Results}

\subsection{Fermentation}

Table 2 presents results of lowering of $\mathrm{pH}$, an increase in acidity (\% of lactic acid) and viability of the probiotics assessed in fermentation.

The $\mathrm{pH}$ decreased to 5.0 in a time of 10 to 13 hours in the formulations that contained the hydrolyzed kiwicha; however, formulations $1 \mathrm{~L}, 1 \mathrm{~B}$ and $1 \mathrm{LB}$, lacked hydrolyzed kiwicha, the $\mathrm{pH}$ did not reach 5 in the fermentation after 18 hours. The acidity increased to $0.06-0.09 \%$ of lactic acid, corresponding to a greater acidity to the formulations with greater contents of hydrolyzed kiwicha. In the 1L, 1B and 1LB formulations, acidity only reached $0.02 \%$ of Lactic Acid. The viability of probiotics in the different formulations was improved in the following order: $3(3 \mathrm{~L}, 3 \mathrm{~B}, 3 \mathrm{LB})>2(2 \mathrm{~L}, 2 \mathrm{~B}, 2 \mathrm{LB})>1(1 \mathrm{~L}, 1 \mathrm{~B}, 1 \mathrm{LB})$.

Variable means followed by capital letters indicate significance difference $(\mathrm{p}<0.05)$ according to Tukey's test.

Table 2. $\mathrm{pH}$, Acidity, ${ }^{\circ} \mathrm{Bx}$ and viability of probiotics in the fermentation process of the drinks.

\begin{tabular}{|c|c|c|c|c|c|c|c|c|c|c|}
\hline \multirow{2}{*}{ Characteristics } & & \multicolumn{9}{|c|}{ Formulation } \\
\hline & & $1 \mathrm{~L}$ & $2 \mathrm{~L}$ & $3 \mathrm{~L}$ & $1 \mathrm{~B}$ & $2 \mathrm{~B}$ & $3 \mathrm{~B}$ & $1 \mathrm{LB}$ & $2 \mathrm{LB}$ & $3 \mathrm{LB}$ \\
\hline \multirow[t]{2}{*}{$\mathrm{pH}$} & Start & 6.7 & 6.66 & 6.4 & 6.7 & 6.66 & 6.4 & 6.7 & 6.66 & 6.4 \\
\hline & End & 5.68 & 5.06 & 4.93 & 6.21 & 5.03 & 5.08 & 6.0 & 4.93 & 5.08 \\
\hline Time (h) & & 18 & 12 & 10 & 18 & 12 & 12.5 & 18 & 12.5 & 11 \\
\hline \multirow[t]{2}{*}{ Acidity (\% lactic acid) } & Start & 0.02 & 0.02 & 0.03 & 0.02 & 0.02 & 0.03 & 0.02 & 0.02 & 0.03 \\
\hline & End & 0.02 & 0.06 & 0.09 & 0.02 & 0.09 & 0.09 & 0.02 & 0.06 & 0.09 \\
\hline \multirow[t]{2}{*}{${ }^{\circ} \mathrm{Bx}$} & Start & 10 & 10 & 10 & 10 & 10 & 10 & 10 & 10 & 10 \\
\hline & End & 9.9 & 9.9 & 9.8 & 9.9 & 9.9 & 9.8 & 9.9 & 9.7 & 9.8 \\
\hline \multirow{2}{*}{$\begin{array}{l}\text { Number of microorganisms } \\
(\mathrm{Ln} C F U / \mathrm{ml})\end{array}$} & Start & 15.52 & 15.52 & 15.52 & 15.52 & 15.52 & 15.52 & 15.69 & 15.69 & 15.69 \\
\hline & End & $19.06 \mathrm{~A}$ & $22.52 \mathrm{~B}$ & $23.81 \mathrm{C}$ & $17.50 \mathrm{D}$ & $19.52 \mathrm{E}$ & $21.79 \mathrm{~F}$ & $17.96 \mathrm{G}$ & $23.03 \mathrm{H}$ & $23.61 \mathrm{H}$ \\
\hline Increase \% & & 122.8 & 145.1 & 153.4 & 112.8 & 125.8 & 140.4 & 114.5 & 146.8 & 150.5 \\
\hline
\end{tabular}




\subsection{Post fermentation}

Table 3 presents results of the decrease of $\mathrm{pH}$, increase in acidity (\% of lactic acid) and viability of the probiotics assessed in post fermentation. The formulations of type 2 and 3 were taken into account, which rendered a greater decrease in the $\mathrm{pH}$, a greater increase of acidity and viability.

Formulations 3L, 3LB, 3B (formulation with higher amount of hydrolyzed kiwicha) reached a lower $\mathrm{pH}$, greater acidity and viability than formulations $2 \mathrm{~L}, 2 \mathrm{LB}, 2 \mathrm{~B}$. The decrease in $\mathrm{pH}$ in

Table 3. $\mathrm{pH}$, acidity, ${ }^{\circ} \mathrm{Bx}$ and viability of probiotics in post fermentation of different types of drinks.

\begin{tabular}{|c|c|c|c|c|c|}
\hline \multirow[b]{2}{*}{ Formulation } & \multirow{2}{*}{$\begin{array}{l}\text { Time } \\
\text { (d) }\end{array}$} & \multirow[b]{2}{*}{$\mathrm{pH}$} & Acidity & \multirow[b]{2}{*}{${ }^{\circ} \mathrm{Bx}$} & \multirow{2}{*}{$\begin{array}{c}\text { Number of } \\
\text { microorganisms } \\
(\mathrm{Ln} \text { CFU/ml) }\end{array}$} \\
\hline & & & (\% lactic acid) & & \\
\hline \multirow[t]{4}{*}{$2 \mathrm{~L}$} & 0 & 5.06 & 0.08 & 9.9 & 22.52 a A \\
\hline & 10 & 4.32 & 0.1 & 9.4 & 27.12 c B \\
\hline & 20 & 3.99 & 0.14 & 9.5 & 31.84 e C \\
\hline & 30 & 3.86 & 0.17 & 9.5 & $37.25 \mathrm{~g} \mathrm{D}$ \\
\hline Increase (\%) & & & & & 165.4 \\
\hline \multirow[t]{4}{*}{$3 \mathrm{~L}$} & 0 & 5.06 & 0.08 & 9.8 & $23.81 \mathrm{~b} \mathrm{E}$ \\
\hline & 10 & 4.09 & 0.14 & 9.9 & $29.42 \mathrm{~d} \mathrm{~F}$ \\
\hline & 20 & 3.85 & 0.18 & 9.3 & $35.13 \mathrm{f} \mathrm{G}$ \\
\hline & 30 & 3.66 & 0.21 & 9.5 & $41.63 \mathrm{~h} \mathrm{H}$ \\
\hline Increase (\%) & & & & & 174.8 \\
\hline \multirow[t]{4}{*}{$2 \mathrm{~B}$} & 0 & 5 & 0.09 & 9.9 & $19.52 \mathrm{i} \mathrm{I}$ \\
\hline & 10 & 4.86 & 0.12 & 9.9 & $22.37 \mathrm{k} \mathrm{J}$ \\
\hline & 20 & 4.8 & 0.14 & 9.8 & $22.67 \mathrm{~m} \mathrm{~K}$ \\
\hline & 30 & 4.61 & 0.15 & 9.75 & $23.03 \mathrm{o} \mathrm{L}$ \\
\hline Increase (\%) & & & & & 118 \\
\hline \multirow[t]{4}{*}{$3 B$} & 0 & 4.99 & 0.09 & 9.8 & $21.79 \mathrm{j} \mathrm{M}$ \\
\hline & 10 & 4.47 & 0.14 & 9.8 & $26.521 \mathrm{~N}$ \\
\hline & 20 & 4.37 & 0.15 & 9.9 & $31.54 \mathrm{n} \mathrm{O}$ \\
\hline & 30 & 4.21 & 0.17 & 9.75 & 35.64 p P \\
\hline Increase (\%) & & & & & 163.6 \\
\hline \multirow[t]{4}{*}{ 2LB } & 0 & 5.03 & 0.07 & 9.7 & $23.03 \mathrm{q} Q$ \\
\hline & 10 & 4.42 & 0.11 & 9.8 & $26.12 \mathrm{~s} \mathrm{R}$ \\
\hline & 20 & 4.12 & 0.14 & 9.9 & $31.24 \mathrm{u} \mathrm{S}$ \\
\hline & 30 & 3.9 & 0.15 & 9.75 & $39.79 \mathrm{w} \mathrm{T}$ \\
\hline Increase (\%) & & & & & 172.8 \\
\hline \multirow[t]{4}{*}{$3 \mathrm{LB}$} & 0 & 5.05 & 0.08 & 9.8 & $23.61 \mathrm{r} \mathrm{U}$ \\
\hline & 10 & 4.3 & 0.14 & 9.8 & $27.23 \mathrm{t} \mathrm{V}$ \\
\hline & 20 & 4.06 & 0.16 & 9.8 & $31.73 \mathrm{v} X$ \\
\hline & 30 & 3.73 & 0.19 & 9.75 & $41.12 \times \mathrm{Y}$ \\
\hline Increase (\%) & & & & & 174.2 \\
\hline
\end{tabular}

drinks with B. bacterium longum SP4 was less intense than in the other drinks. The acidity values were inversely proportional to $\mathrm{pH}$ values and it was greater with kiwicha's liquid fraction hydrolizate in formulations. The Brix degrees decreased during post fermentation.

Variable means followed by lowercase letters indicate significance difference (Tukey's test, $\mathrm{p}<0.05$ ) in the number of microorganisms for each group of beverages containing the same probiotic. Variable means followed by capital letters indicate significance difference in each formulation according to the Dunnet's test.

\subsection{Kinetic growth parameters}

Table 4 details the kinetic parameters in the fermentation and post fermentation.

In the fermentation stage, formulations $1 \mathrm{~L}, 1 \mathrm{~B}$ and $1 \mathrm{LB}$ that do not contain the hydrolyzed kiwicha, present specific growth speeds $(\mu)$ lower than to the other formulations that do contain hydrolyzed kiwicha; the duplication times (td) are greater than the rest of the formulations. Among type 2 and 3 formulations, those of type $3(3 \mathrm{~L}, 3 \mathrm{~B}$ and $3 \mathrm{LB}$ ) present better kinetic behavior compared to those of type 2 (2L, $2 \mathrm{~B}$ and $2 \mathrm{LB}$ ). This better kinetic behavior can be seen when the value of the HLK content is greater.

The values of $\mu$ and td are calculated with the number of microorganisms at the beginning and at the end of the fermentation according to the values indicated in Table 2 .

In like manner, during post fermentation, formulations $3 \mathrm{~L}, 3 \mathrm{LB}$ and $3 \mathrm{~B}$ with greater content of hydrolyzed kiwicha, present specific speeds greater than formulations $2 \mathrm{~L}, 2 \mathrm{~B}$ and 2LB, showing lower duplication times.

Figure 1 shows the growth in probiotics used for the drinks formulated in post fermentation; the figures $\mathrm{a}, \mathrm{b}$, and $\mathrm{c}$ show the kinetic equations for each type of drink for 30 days at $5^{\circ} \mathrm{C}$.

In addition, velocity constant in the equations is represented by the slope of the equation expressed in $(1 / d)$. In Table 4 it appears as the specific speed of growth $(\mu)$ expressed in $1 / \mathrm{h}$, which results from dividing the speed constant of each equation between $24 \mathrm{~h}$. Duplication times (td) results from dividing the value of 0.693 between the values of the specific velocity $(\mu)$ according to the growth kinetics of microorganisms in discontinuous crops.

Table 4. Kinetic parameters of viability of probiotic drinks during fermentation and post fermentation.

\begin{tabular}{|c|c|c|c|c|c|c|c|c|c|}
\hline \multirow{2}{*}{$\begin{array}{c}\text { Kinetic } \\
\text { Parameters }\end{array}$} & \multicolumn{9}{|c|}{ Formulation } \\
\hline & $1 \mathrm{~L}$ & $2 \mathrm{~L}$ & $3 \mathrm{~L}$ & $1 \mathrm{~B}$ & $2 \mathrm{~B}$ & $3 \mathrm{~B}$ & $1 \mathrm{LB}$ & $2 \mathrm{LB}$ & $3 \mathrm{LB}$ \\
\hline & \multicolumn{9}{|c|}{ Fermentation } \\
\hline$\mu(1 / h)$ & 0.1968 & 0.589 & 0.8294 & 0.1102 & 0.3333 & 0.5014 & 0.1262 & 0.5871 & 0.7206 \\
\hline \multirow[t]{2}{*}{$\mathrm{td}(\mathrm{h})$} & 3.52 & 1.19 & 0.84 & 6.29 & 2.08 & 1.38 & 5.49 & 1.18 & 0.96 \\
\hline & \multicolumn{9}{|c|}{ Post Fermentation } \\
\hline$\mu(1 / h)$ & --- & 0.0204 & 0.0247 & --- & 0.0045 & 0.0194 & --- & 0.0231 & 0.0238 \\
\hline $\mathrm{td}(\mathrm{h})$ & --- & 34 & 28.1 & --- & 153.7 & 35.7 & --- & 30 & 29.2 \\
\hline
\end{tabular}



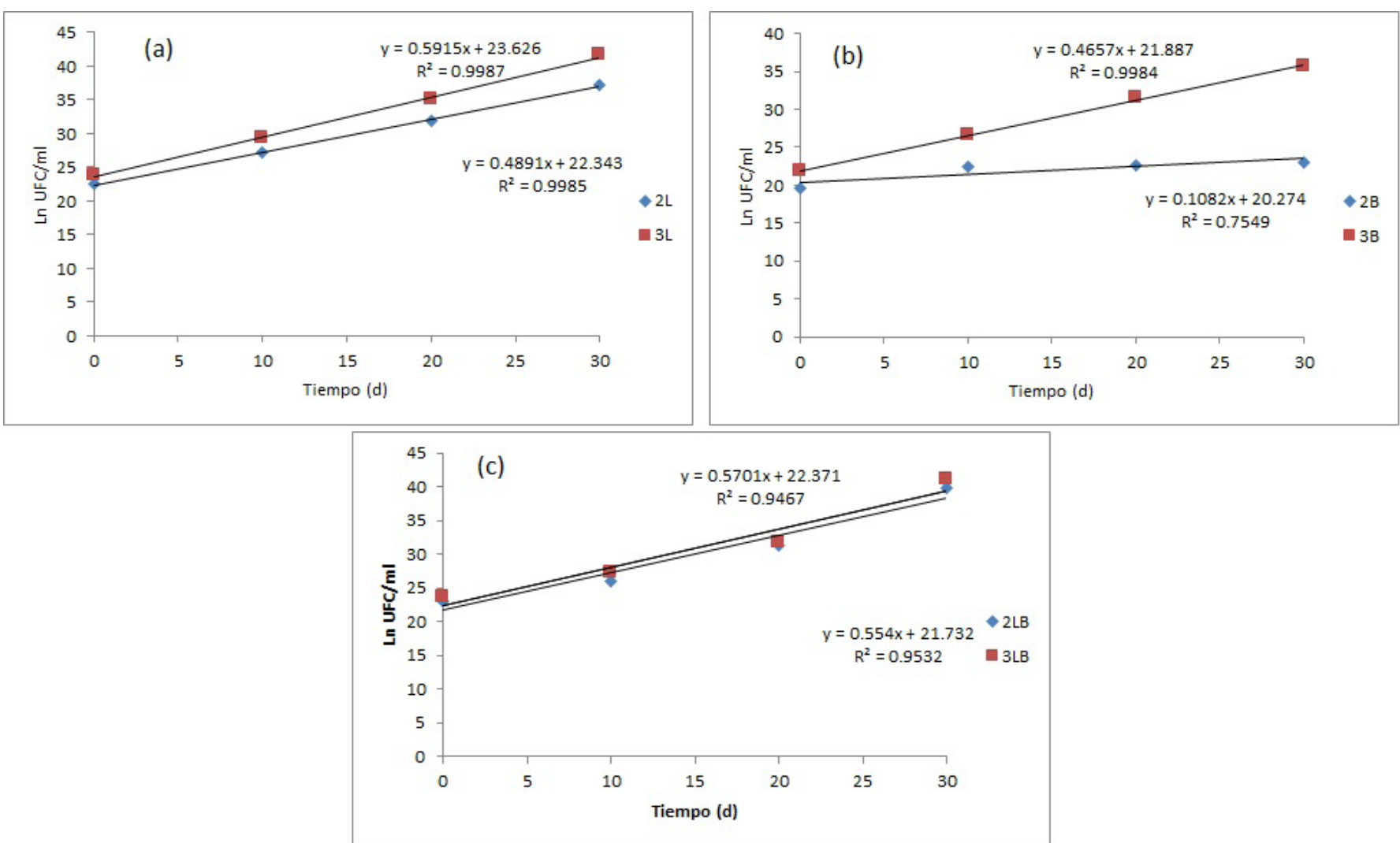

Figure 1. Growth of probiotics in post-fermentation: (a) Lactobacillus paracasei BGP1 (L); (b) Bifido bacterium longum SP54 (B); (c) Co culture in probiotic drinks of tarwi juice and liquid hydrolyzed kiwicha (LB).

\subsection{Characteristics of drinks}

Table 5 details the proximal chemical composition of drinks elaborated with basic formulation 2 and 3; a low content of fat, a percentage of sugars of about $10 \%$ and contents of protein close to $1 \%$ can be observed.

\subsection{Sensorial assessment}

The statistical results in the hedonic test and shelf life showed that there is no significant difference between the different drinks. In the hedonic test, the rating was within the range of 5 and 6 (I slightly like it - I like it), and in shelf life, it was within the range of 4 and 5 (acceptable - good.) With the presence of strawberry and orange flavors, the drinks were rated on the scale of 6 and 7 (I like it - I like it a lot).

\section{Discussion}

The analysis of the results of the formulations assessed during fermentation indicates that the viability of the probiotics used was lower than in formulations $1 \mathrm{~L}, 1 \mathrm{~B}$ and $1 \mathrm{LB}$ with respect to the others. In each group of drinks, according to the probiotic type, there were significant differences in the $\mathrm{CFU} / \mathrm{ml}$ number at the end of the fermentation. The growth of Bifido bacterium longum SP54 was slow; the viability is good when the mixture interacts with lactobacillus paracasei BGP1.
Table 5. Proximal chemical analysis of probiotic drinks elaborated with tarwi juice and hydrolyzed kiwicha.

\begin{tabular}{ccc}
\hline Analysis & Formulation 2 & Formulation 3 \\
\hline Water $(\%)$ & 89 & 88.9 \\
Dry extract $(\% \mathrm{p} / \mathrm{p})$ & 11 & 11.1 \\
Protein $(\% \mathrm{p} / \mathrm{p})$ & 0.85 & 0.81 \\
Fat $(\mathrm{g} / 100 \mathrm{ml} \%)$ & 0.06 & 0.1 \\
Ashes $(\mathrm{g} / 100 \mathrm{ml} \%)$ & 0.08 & 0.1 \\
Carbohydrates $(\%)$ & 10 & 10.1 \\
Sodium $(\mathrm{mg} / \mathrm{L})$ & 128 & 57.75 \\
Calcium $(\mathrm{mg} / \mathrm{L})$ & 112.5 & 109.25 \\
Caloric value $(\mathrm{Kcal} / 100 \mathrm{~g})$ & 43.94 & 44.6 \\
\hline
\end{tabular}

Mondragon (2004) reported the use of soy hydro-soluble extract; pure cultures of $L$. paracasei subsp. Paracasei LBC81 and Bifido bacterium longum BL04 had a growth of 27.6 - $29.9(\mathrm{Ln}$ CFU/ml) between 16-20 h of fermentation, while L. acidophilus LAC4 with the presence of $B$. longum BL04, had an increase in the number of cells (23.0 - 29.9) between 20-24h of fermentation, the initial number of microorganisms employed was from $13.1-17.7$ ( $\mathrm{Ln} \mathrm{CFU} / \mathrm{ml}$ ). In this research, the fermentation times using hydrolyzed kiwicha and tarwi juice to reach a $\mathrm{pH}$ of 5.0 were lower than those detailed. Other authors found synergic activity with co-cultures of Bifido bacterium and lactobacillus in the growth of microorganisms when acting over fractions of dietary fiber of rice, the growth was limited when a pH of $4.2-4.45$ was 
reached (Fernando et al., 2011). There is a similarity with the results found in this research due to the synergic effect of the lactobacillus paracasei BGP1 with the B. bacterium longum SP54, compared to the use of the bifid bacterium SP54; the lactobacillus paracasei BGP1 had a significant growth as a pure culture.

The analysis of the results of the 6 formulations assessed during post fermentation indicates that the viability of probiotics is greater when the content of liquid hydrolyzed kiwicha is increased. According to the Tuckey test performed $(\mathrm{p}<0.05)$, there are significant differences between the pairs $2 \mathrm{~L}-3 \mathrm{~L}, 2 \mathrm{~B}-3 \mathrm{~B}$, 2LB-3LB for the different times assessed 0, 10, 20, and $30 \mathrm{~d}$. Table 3 shows these differences with the small letters between pairs of the same type of drink, but with a different content of hydrolyzed kiwicha. The Dunnet test performed with respect to the initial population in each type of drink showed an increase in the significant differences in the course of post fermentation; Table 3 shows these differences with capital letters. The greatest variability of probiotics in substrates that have liquid hydrolyzed kiwicha may be due to the presence of oligosaccharides of the families of raffinose, stachyose, oligosaccharides present in kiwicha and non-hydrolyzed by amylase alfa and the amyloglucosidase as it was noted by other authors (Maza, 2000). Besides, it was reported that the presence of raffinose had beneficial effects on the survival of the Bifido bacterium lactis and lactobacillus acidophilus for 21 days of storage at $5^{\circ} \mathrm{C}$ in fermented milk (Prado et al., 2008).

It is observed that the viability of probiotics used remains still in the low $\mathrm{pH}$ values, an important quality in this type of products (Prado et al., 2008). The results show better resistance to the decrease in $\mathrm{pH}$ for formulations of type $3 \mathrm{~L}, 2 \mathrm{~L}, 3 \mathrm{LB}$ and $2 \mathrm{LB}$, which in the case of the formulations with only Bifido bacterium longum, the growth of the latter decreases when the $\mathrm{pH}$ drops, a situation also observed in the fermentation stage. A lower $\mathrm{pH}$ of 4.5 - 5.0 does not stimulate its growth (Gomes \& Malcata, 1999). On the other hand, the $\mathrm{pH}$ achieved in formulations $3 \mathrm{~B}$ is in a favorable range $<$ of 4.5 , which is in relation with the contents of liquid hydrolyzed kiwicha. It must also be noted that lower values in $\mathrm{pH}$ benefit the preservation and prevent the development of harmful bacteria in the prepared products (Prado et al., 2008).

The kinetic parameters determined during fermentation and post-fermentation (Table 4 ) indicate the best viability of the probiotics in the formulations of type 3 compared to formulations of type 2. The kinetic behavior will depend on the type of strain, culture medium and processing conditions (Acevedo et al., 2010; 2013).

The sensory results are important and are related to the quality of the product, processing, and composition of the substrate used and the concentration of its components (Escalante et al., 2016; Dongmo et al., 2016). In that sense, the formulations designed including the portion of kiwicha's liquid hydrolyzed to tarwi juice, not only did it improve the viability of the probiotics used, but it also improved their sensorial characteristics. The chemical characteristics of these products vary considerably depending on the type of culture used, the substrate and the processing, during which variations take place in the $\mathrm{pH}$ and the acidity that lead to the formation of organic acids in relation with the levels of reduction of the contents of sugars, generation of amino acids, and other metabolites associated with flavor (Waters et al., 2015).
The drinks containing HLK have a high number of CFU/ml, which ensures the minimum required of $10^{8}-10^{9}$ cells/g of the product at the time of consumption (Prado et al., 2008; Vera-Pingitore et al., 2016; Kandylis et al., 2016). This high viability is very favorable as the success of the new drinks depends on the ability of the probiotics to provide a high enough number of viable cells beneficial to the intestinal microbial flora of the consumer (Shori, 2016).

The beverages contained proteins, fat, dry extract, ashes and carbohydrates $(0.8-0.85,0.06-0.1,11,0.08-0.10$ and $10 \%$, respectively), sodium $(58-128 \mathrm{mg} / \mathrm{L})$ and calcium $(109-113 \mathrm{mg} / \mathrm{mL})$ and a caloric value of $44-45 \mathrm{kcal} / 100 \mathrm{~g}$ and various probiotic bacteria such as Lactobacillus paracasei and Bifido bacterium longum and their mixtures.

The drinks prepared within this research are lactose free and have a low content of carbohydrates.

The research carried out allowed for the diversification in the use of tarwi and kiwicha as raw materials in the preparation of probiotic drinks. As a result of carrying out this research, a technology has been developed that generates new formulations and fermentation processes using probiotics for the preparation of new types of drinks from tarwi juice and hydrolyzed kiwicha in a liquid state.

The hypothesis was confirmed since the results show that the presence of hydrolyzed kiwicha in its liquid form (HLK) in the formulations with tarwi juice generates favorable effects in the viability of probiotic bacteria used. The fermentation of substrates with only tarwi juice and sucrose did not show such viability; besides, the formulations designed and the processes developed led to the preparation of drinks with favorable sensorial characteristics.

\section{Conclusions}

The use of the liquid portion of hydrolyzed kiwicha in the production of probiotic drinks with tarwi juice improve the viability of the lactic bacteria assessed, especially when the amount of hydrolyzed increased. The formulations containing tarwi juice and sucrose were not favorable in the growth of microorganisms, decrease in $\mathrm{pH}$ and increase in acidity. The growth of probiotic microorganisms reached values higher than $10^{8} \mathrm{CFU} / \mathrm{ml}$ at the end of the fermentation, which ensured the minimum required at the time of consumption. The viability of the microorganisms assessed increases during post-fermentation even with low $\mathrm{pH}$; the monoculture of lactobacillus paracasei and the co-culture of lactobacillus paracasei with Bifido bacterium longum showed favorable effects compared with the single use in the monoculture of Bifido bacterium longum, whose growth slows down with the decrease in $\mathrm{pH}$. The values of $\mathrm{pH}$ and acidity benefit the stability of fermented drinks against the growth of pathogen microorganisms. In addition, sensorial characteristics of the drinks prepared were favorable.

\section{References}

Acevedo, D., Guzmán, L., \& Rodríguez, A. (2013). Cinética de Fermentación en la producción de suero costeño. Revista Udca Actualidad \& Divulgacion Cientifica, 16(2), 427-433. 
Acevedo, D., Rodríguez, A., \& Fernández, A. (2010). Efecto de las Variables de Proceso sobre la Cinética de Acidificación, la Viabilidad y la Sinéresis del Suero Costeño Colombiano. Información Tecnológica, 21(2), 29-36.

Anzaldua, A. (1994). La evaluación sensorial de los alimentos en la teoría y la práctica. España, Editorial Acribia S.A.

Benavides, M. A., \& Quicazan, M. C. (2009). Valoración de diferentes indicadores de la fermentación de bebida de soya y de leche de vaca utilizando cultivos probióticos. Brazilian Journal of Food Technology, 12(esp), 100-106. VII BMCFB.

Carrillo, W. I., Vilacundo, R., \& Carpio, C. (2015). Compuestos bioactivos derivados de amaranto y quinua. Actualización en Nutrición, 16(1), 18-22.

Carvajal-Larenas, F. E., Linnemann, A. R., Nout, M. J., Koziol, M., \& van Boekel, M. A. (2016). Lupinus mutabilis: Composition, Uses, Toxicology and Debittering. Critical Reviews in Food Science and Nutrition, 56(9), 1454-1487. http://dx.doi.org/10.1080/10408398.2 013.772089. PMid:26054557.

Castañeda, B., Manrique, R., Gamarra, F., Muñoz, A., Ramos, F., Lizarazo, F., \& Martinez, J. (2008). Probiótico elaborado en base de las semillas de Lupinus mutabilis sweet (chocho o tarwi). Acta Médica Peruana, 25(4), 210-215.

Dongmo, S. N., Procopio, S., Sacher, B., \& Becker, T. (2016). Flavor of lactic acid fermented malt based beverages: Current status and perspectives. Trends in Food Science \& Technology, 54, 37-51. http:// dx.doi.org/10.1016/j.tifs.2016.05.017.

Escalante, A., Soto, D. R. L., Gutiérrez, J. E. V., Giles-Gómez, M., Bolívar, F., \& López-Munguía, A. (2016). Pulque, a Traditional Mexican Alcoholic Fermented Beverage: Historical, Microbiological, and Technical Aspects. Frontiers in Microbiology, 7, 1026. http://dx.doi. org/10.3389/fmicb.2016.01026. PMid:27446061.

Espinoza, E. (2003). Evaluación sensorial de los alimentos. Tacna, Perú: Universidad Nacional Jorge Basadre Grohmann.

Fernando, W. M., Flint, S., Zou, M., Brennan, C. S., Ranaweera, K. K., \& Bamunuarachchi, A. (2011). The effect of rice fibre fractions on the growth of co-cultures of probiotics. Journal of Food Science and Technology, 48(1), 14-25. http://dx.doi.org/10.1007/s13197-0100147-5. PMid:23572712.

Gomes, A., \& Malcata, F. X. (1999). Bifidobacterium spp. And Lactobacillus acidophilus: biological, biochemical, technological and therapeutical properties relevant for use as probiotics. Trends in Food Science \& Technology, 10(4-5), 139-157. http://dx.doi. org/10.1016/S0924-2244(99)00033-3.

Jacobsen, S. E., \& Mujica, A. (2006). El tarwi (Lupinus mutabilis Sweet.) y sus parientes silvestres. In M. Moraes, B. Øllgaard, L. P. Kvist, F. Borchsenius \& H. Balslev (Eds.), Botánica económica de los andes centrales (pp. 458-462). La Paz: Universidad Mayor de San Andrés.

Jiménez-Martínez, C., Hernández-Sánchez, H., \& Dávila-Ortiz, G. (2003). Production of a yogurt-like product from Lupinus campestris seeds. Journal of the Science of Food and Agriculture, 83(6), 515-522. http://dx.doi.org/10.1002/jsfa.1385.

Kandylis, P., Pissaridi, K., Bekatorou, A., Kanellaki, M., \& Koutinas, A. A. (2016). Dairy and non-dairy probiotic beverages. Current Opinion in Food Science, 7, 58-63. http://dx.doi.org/10.1016/j.cofs.2015.11.012.

Londoño, M. M., Sepúlveda, J. U., Hernández, A., \& Parra, E. (2008). Bebida fermentada de suero de queso fresco inoculada con Lactobacillus casei. Revista Facultad Nacional de Agronomía, 61(1), 4409-4421.

Manzano, C., Estupiñan, D., \& Poveda, E. (2012). Efectos clínicos de los probióticos: qué dice la evidencia. Revista Chilena de Nutrición, 39(1), 98-110.
Mayorga, L., Bustamante, P., Gutiérrez, A., Barranco, E., \& Azaola, A. (2009). Crecimiento, sobrevivencia y adaptación de Bifidobacterium infantis a condiciones acidas. Revista Mexicana de Ingeniería Química, 8(3), 259-264.

Maza, G. (2000). Alimentos funcionales, aspectos bioquímicos y de procesado. Zaragoza: España Editorial Acribia S.A.

Mokoena, M. P., Mutanda, T., \& Olaniran, A. O. (2016). Perspectives on the probiotic potential of lactic acid bacteria from African traditional fermented foods and beverages. Food \& Nutrition Research, 60, 29630. http://dx.doi.org/10.3402/fnr.v60.29630. PMid:26960543.

Mondragon, O. L. (2004). Desenvolvimento de uma bebida fermentada a partir de extrato hidrossolúvel de soja, contendo agentes probióticos e prebióticos (Dissertação de Mestrado). Facultade de Engenharia de Alimentos, Universidade Estadual de Campinas, Campinas.

Obando, M., Brito, C. S., Schöbitz, R. P., Baez, L. A., \& Horzella, M. Y. (2010). Viabilidad de los microorganismos probioticos Lactobacillus casei 01, Lactobacillus acidophilus La-5, Bifidobacterium BB12, durante el almacenamiento de queso cottage. Ciencia, Tecnologia e Ingenieria, 17(2), 141-148.

Prado, F. C., Parada, J. L., Pandey, A., \& Soccol, C. R. (2008). Trends in non-dairy probiotic beverages. Food Research International, 41(2), 111-123. http://dx.doi.org/10.1016/j.foodres.2007.10.010.

Reis, S., Ghiselli, G., \& Maugeri, F. M. Fo. (2012). Development of a soy-based synbiotic beverage. Food and Nutrition Sciences, 3(8), 1128-1135.

Repo, R. (2014). Valor nutricional y compuestos bioactivos en los cultivos andinos. Perú: Fondo Editorial Universidad Agraria La Molina.

Shah, N. P., Lankaputhra, W. E. V., Britz, M. L., \& Kyle, W. S. A. (1995). Survival of Lactobacillus acidophilus and Bifidobactevium bifidum in commercial yoghurt during refrigerated storage. International Dairy Journal, 5(5), 515-521. http://dx.doi.org/10.1016/09586946(95)00028-2.

Shori, A. B. (2016). Influence of food matrix on the viability of probiotic bacteria: a review based on dairy and non-dairy beverages. Food Bioscience, 13, 1-8. http://dx.doi.org/10.1016/j.fbio.2015.11.001.

Silva, L. S., Souza, A. C., Maria, M. M., Jardim, A. B., Silva, W., Pires, C. V., Souza, M. R., \& Silva, A. (2014). Estudo da viabilidade de Bifidobacterium longum em bebidas lácteas probióticas. In XII Congresso Latino Americano de Microbiologia e Higiene de Alimentos (vol. 1, no. 1, pp. 309-310). São Paulo: Blucher Proceedings. http:// dx.doi.org/10.5151/foodsci-microal-155.

Tamang, J. P., Shin, D. H., Jung, S. J., \& Chae, S. W. (2016a). Functional Properties of Microorganisms in Fermented Foods. Frontiers in Microbiology, 7, 578. http://dx.doi.org/10.3389/fmicb.2016.00578. PMid:27199913.

Tamang, J. P., Watanabe, K., \& Holzapfel, K. (2016b). Review: diversity of microorganisms in global fermented foods and beverages. Frontiers in Microbiology, 7, 377. PMid:27047484.

Vera-Pingitore, E., Jimenez, M. E., Dallagnol, A., Belfiore, C., Fontana, C., Fontana, P., von Wright, A., Vignolo, G., \& Plumed-Ferrer, C. (2016). Screening and characterization of potential probiotic and starter bacteria for plant fermentations. Lebensmittel-Wissenschaft + Technologie, 71, 288-294. http://dx.doi.org/10.1016/j.lwt.2016.03.046.

Waters, D. M., Mauch, A., Coffey, A., Arendt, E. K., \& Zannini, E. (2015). Lactic acid bacteria as a cell factory for the delivery of functional biomolecules and ingredients in cereal based beverages: a review. Reviews in Food Science and Nutrition, 55(4), 503-520. http://dx.doi. org/10.1080/10408398.2012.660251. PMid:24915367. 